\title{
Preparation of Laser-Modified Ti-15Mo Surfaces With Multiphase Calcium Phosphate Coatings
}

\author{
Marcio Luiz dos Santos ${ }^{a}$,Edson de Almeida Filho ${ }^{b}$, Vagner Pereira da Silva ${ }^{a}$, Ricardo L. Tranquilin',

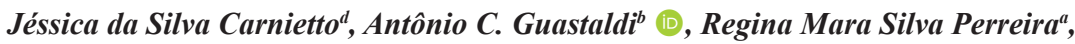 \\ Carla dos Santos Riccardi ${ }^{d *}$ (D) \\ ${ }^{a}$ Universidade Anhanguera de São Paulo, Programa de Biotecnologia e Inovação em Saúde, Programa \\ de Mestrado Profissional em Farmácia, São Paulo, SP, Brasil \\ ${ }^{b}$ Universidade Estadual Paulista, Instituto de Química, Grupo de Biomateriais, Araraquara, SP, Brasil \\ ${ }^{c}$ Universidade Federal do Rio Grande do Norte, Laboratório de Síntese Química de Materiais, Natal, \\ $R N$, Brasil \\ ${ }^{d}$ Universidade Estadual Paulista, Faculdade de Ciências Agronômicas, Botucatu, SP, Brasil
}

Received: October 28, 2019; Revised: June 19, 2020; Accepted: August 10, 2020

\begin{abstract}
Multiphasic bioceramic scaffolds has been enhanced for dental and orthopedic applications. In this perspective, the laser surface texturing of metallic surfaces combined to bioactive calcium phosphate coatings have shown to be promising and economically feasible for biomaterial clinical applications. Ti-15Mo alloy samples were irradiated by pulsed Yb: YAG laser beam. The formation of HA and other calcium phosphates phases by biomimetic method should occur in the presence of $\mathrm{Ca}^{2+}, \mathrm{PO}_{4}^{3-}, \mathrm{Mg}^{2+}$, $\mathrm{HCO}^{3-}, \mathrm{K}^{+}$and $\mathrm{Na}^{+}$. The modified surfaces were submitted to thermal treatment at 380 and $580^{\circ} \mathrm{C}$. The results showed the processes of fusion and fast solidification from the laser beam irradiation, inducing the formation of stoichiometric $\alpha-\mathrm{Ti}, \mathrm{TiO}_{2}$ and non-stoichiometric titanium oxides, $\mathrm{Ti}_{3} \mathrm{O}$ and $\mathrm{Ti}_{6} \mathrm{O}$ with different oxide percentages depending on applied fluency (fluency of $0.023,0.033,0.040$ and $0.048 \mathrm{~J} / \mathrm{mm}^{2}$ ). The morphological and physicochemical properties have indicated the formation of a multiphase bioceramic coatings. It was observed the formation of amorphous calcium phosphate (ACP), octacalcium phosphate (OCP), and magnesium phosphate $\left(\mathrm{Mg}_{3}\left(\mathrm{PO}_{4}\right)_{2}\right)$ phases at $380^{\circ} \mathrm{C}$, whereas $\beta$ - $\mathrm{TCP}$ (tricalcium phosphate), OCP, and substituted $\beta$-TCP with $\mathrm{Ca}_{2,589} \mathrm{Mg}_{0,41}\left(\mathrm{PO}_{4}\right)_{2}$ were obtained at $580^{\circ} \mathrm{C}$. Therefore, the multiphasic bioceramic modified Ti-15Mo surface could enhance osteointegration for bone regeneration.
\end{abstract}

Keywords: Ti-15Mo alloy, biomimetic coatings, calcium phosphates, laser ablation.

\section{Introduction}

Calcium phosphates has been used in a variety of applications for the treatment of the bone system, since insulated material that surface coating of metallic implants ${ }^{1-7}$. The clinical limitations of the use of hydroxyapatite (HA) phase, due to its slow biodegradation, has aroused the interest in the others calcium phosphates phases, including amorphous calcium phosphate (ACP), octacalcium phosphate (OCP), magnesium phosphate $\left(\mathrm{Mg}_{3}\left(\mathrm{PO}_{4}\right)_{2}\right)^{8-12}$. In this context, magnesium has been considered the most important ion used in calcium substitution, promoting a change in the biological and chemical behavior of these materials ${ }^{12-15}$.

The biomimetic coating method is based on the heterogeneous precipitation on titanium substrates and their alloys. The nucleation and growth of the calcium phosphate coating occurs after immersion in a balanced salt solution (Hank's solution or SBF) at $37^{\circ} \mathrm{C}$ for several days $\mathrm{s}^{4,16}$. This process is similar to the process of bone biomineralization ${ }^{4,17,18}$. The modified biomimetic method represented a major advance in the area of biomaterials. The growing interest in the use

*e-mail: carla.riccardi@unesp.br of other phases of calcium phosphates has resulted in more promising properties than the HA phase, new strategies have been described in bioceramic coating on metal surfaces ${ }^{16,19}$.

In our previous work ${ }^{2}$, Ti-Mo laser-activated surfaces were coated by sol-gel calcium phosphates, indicating a mixture of phases under diferents temperature control. As a continuation of our previous work, this study has evaluated six different simulated body fluid solutions, which were called modified $\mathrm{SBF}$, in order to design a multiphase bioceramic coatings with controlled chemical deposition on metallic surface. The aim of this work was to evaluate the morphological and physicochemical properties of the surfaces of the Ti-15Mo alloy modified by Yb: YAG laser beam, as well as deposition of bioactive ceramics using the modified biomimetic method.

\section{Materials and Methods}

\subsection{Laser-activated surface modification}

Samples of Ti-15Mo alloy (4 mm length, $4 \mathrm{~mm}$ wide, $2 \mathrm{~mm}$ thick) were submitted to Yb:YAG multipulse laser irradiation using a Laser OmniMark 20 F (OmniTek, São 
Paulo, Brazil) $(\lambda=1090 \mathrm{~nm})$ at a short exposition time (1 minute). Our research group has evaluated the topography of metallic surfaces in order to relate parameters of Ti-15Mo surface, such as morphology and roughness and surface energy, depend on the formed phases ${ }^{2,3}$. The surfaces were modified under ambient pressure and air, using the parameters (power, frequency and scan speed) with four fluency (ablation) of $0.023,0.033,0.040$ and $0.048 \mathrm{~J} / \mathrm{mm}^{2}(\mathrm{n}=5$ for each treatment), respectively (Table 1). After irradiation, the samples were treated ultrasonically and separately in solutions of ethyl alcohol, acetone and deionized water, followed by oven-drying and characterization.

\subsection{Preparation of the modified SBF solution and biomimetic coating}

The irradiated samples were immersed in modified SBF solution (SBFMg). This solution contained different ions in order to improve the formation of the phases of interest. The reagents used were: $\mathrm{NaCl}, \mathrm{K}_{2} \mathrm{HPO}_{4}, \mathrm{CaCl}_{2} .2 \mathrm{H}_{2} \mathrm{O}, \mathrm{MgCl}_{2} .2 \mathrm{H}_{2} \mathrm{O}$ and $\mathrm{HCl}$ supplied by J. T. Baker; Tris (hydroxymethyl) aminomethane was purchased from Mallinckrodt. Table 2 indicates the ionic concentrations of the SBFMg solution used to obtain the calcium phosphate coatings on the laser beam irradiated Ti-15Mo surfaces. The preparation of the SBFMg solution was modified from reported protocol by Aparecida (2007), in order to minimize the possibility of solution loss caused by its precipitation.

The substrates were washed sequentially with alcohol, acetone and deionized water. To obtain the calcium phosphate coatings using the SBFMg solution, all the samples were immersed in $50 \mathrm{~mL}$ of modified SBF solution $(\mathrm{pH} 7.4)$, and remained in controlled temperature condition at $37^{\circ} \mathrm{C}$ for 4 days ${ }^{11,16,20}$. The solution was exchanged every 24 hours for the purpose of promoting the super-saturation conditions of the solution and, consequently, inducing the formation of the calcium phosphate coating. After the period to obtain the coatings, the samples were air dried and submitted to thermal treatment at 380 and $580^{\circ} \mathrm{C}$ for 3 hours, without atmospheric control. The heating and cooling rate used was $5^{\circ} \mathrm{C} /$ minute.

\subsection{Characterization}

All the coated and uncoated samples were characterized by scanning electron microscopy (SEM), using a Zeiss EVO LS-15, with EDS/EBDS Oxford INCA Energy 250 system. The X-ray diffraction analysis was performed in a Siemens D5000 X-ray diffractometer, using a scan angle of 5 at $60^{\circ}$ with a step size of $0.02(2 \theta)$. Each sample was subjected to a counting time of $10 \mathrm{~s} /$ step in a Bragg-Brentano configuration, using $\mathrm{Cu}(\mathrm{k} \alpha 1)$ radiation. Quantification by Rietveld refinement was performed in a Rigaku RINT-2000 X-ray diffractometer with rotating anode, operating under the experimental

Table 1. Fluency obtained by irradiation of the laser beam.

\begin{tabular}{ccccc}
\hline Samples & Am1 & Am2 & Am3 & Am4 \\
\hline Fluency $\left(\mathrm{J} / \mathrm{mm}^{2}\right)$ & $\mathbf{0 . 0 2 3}$ & $\mathbf{0 . 0 3 3}$ & $\mathbf{0 . 0 4 0}$ & $\mathbf{0 . 0 4 8}$ \\
\hline
\end{tabular}

conditions of $42 \mathrm{KV}, 120 \mathrm{~mA}$, with divergence slits, scattering angle of $0.5^{\circ}, 5 \mathrm{~mm}$ horizontal opening of the divergence slit, $0.3 \mathrm{~mm}$ receiving signal, $5^{\circ}$ Soller, copper anode, and wavelengths of $\mathrm{K} \alpha_{1}=1.55056 \AA$ and $\mathrm{k} \alpha_{2}=1.5444 \AA$, $\mathrm{I} \alpha_{2} / \mathrm{I} \alpha_{1}=0.5$. The chemical bonds of the calcium phosphates coatings were characterized by vibrational infrared spectroscopy, using a Bruker Vertex 70 FTIR spectrophotometer equipped with a diffuse reflection DRIFT Collector ${ }^{\mathrm{TM}}$.

\section{Results and Discussions}

\subsection{Morphological properties}

The micrographies of the surfaces of the uncoated samples Ti-15Mo alloy submitted to laser beam using different fluencies $\left(0.023,0.033,0.040\right.$ and $0.048 \mathrm{~J} / \mathrm{mm}^{2}$, respectively) are presented in Figure 1A. It can be observed the increased fluency, due to longer exposure time of the laser beam to the alloy surface, promotes typical morphologies with different surface energies. This can be explained through the formation of new structures (metal oxides) produced during the fast melt and solidification process ${ }^{2,3,21}$

Figure 1B shows the morphologies of the coatings obtained in samples 1, 2, 3 and 4, using the SBFMg solution and heat treated at $380^{\circ} \mathrm{C}$. It was possible to identify the formation of a coating with morphology characteristic of the ACP 2, OCP and $\mathrm{Mg}_{3}\left(\mathrm{PO}_{4}\right)_{2}$ phases $2,6,10,12,13,17,18,22$.

The morphologies of the coatings obtained for samples 1 , 2, 3 and 4, using the SBFMg solution and heat treatment treated $580^{\circ} \mathrm{C}$ are presented in Figure $1 \mathrm{C}$. The formation of a multiphase coating was evidenced, evidenced by the presence of particles with different morphologies and size, characteristic of the phases of $\beta$-TCP, TCP replaced with magnesium - $\mathrm{Ca}_{2,589} \mathrm{Mg}_{0,41}\left(\mathrm{PO}_{4}\right)_{2}{ }^{23,24}$, magnesium phosphate $\left[\mathrm{Mg}_{3}\left(\mathrm{PO}_{4}\right)_{2}\right]^{23,25}$ e OCP $\mathrm{P}^{13,17,22,26}$. The presence of magnesium phosphate phases resulted in the absence of calcium deficient HA or HA, since these compounds present crystallization temperatures from $580^{\circ} \mathrm{C}$, inhibiting the conversion of calcium phosphates to $\mathrm{HA}^{27,28}$. According to the literature, the $\mathrm{Mg}^{2+}$ ion inhibits HA growth, since it complexes more easily with $\mathrm{PO}_{4}^{3-}$ ions than $\mathrm{Ca}^{2+}$ ions ${ }^{17,18,22}$.

\subsection{XRD Rietveld refinement}

Figure 2 shows the diffractograms of samples $(0.023$, $0.033,0.040$ and $0.048 \mathrm{~J} / \mathrm{mm}^{2}$ ), respectively.

It was possible to produce the formation of stoichiometric and non-stoichiometric oxides as predicted by the fluency equation. X-ray diffraction spectra revealed (Figure 2A), in addition to $\alpha$-Ti peaks (\#: 89-4913), the presence of $\mathrm{TiO}_{2}$ (\#:77-441), $\mathrm{Ti}_{3} \mathrm{O}$ (\#: 76-1644), $\mathrm{Ti}_{6} \mathrm{O}$ (\#: 72-1471) and was in accordance with Joint Committee Powder Diffraction Standard ${ }^{29}$.

Table 3 shows the oxide phases percentage obtained by Rietveld refinement, corresponding to laser beam-irradiated Ti-15Mo surfaces ${ }^{30,31}$. It can be observed the fusion and solidification process under ambient air, inducing the

Table 2. The ionic concentrations of the solution SBFMg $\left(\mathrm{nmol} . \mathrm{mm}^{-3}\right)$

\begin{tabular}{|c|c|c|c|c|c|c|c|c|}
\hline & $\mathbf{N a}^{+}$ & $\mathbf{K}^{+}$ & $\mathrm{Mg}^{2+}$ & $\mathrm{Ca}^{2+}$ & $\mathrm{Cl}^{-}$ & $\mathrm{HPO}_{4}{ }^{2-}$ & $\mathrm{SO}_{4}{ }^{2-}$ & $\mathrm{HCO}_{3}$ \\
\hline SBFMg & 45,30 & - & 0,32 & 1,00 & 46,09 & 0,60 & - & - \\
\hline
\end{tabular}


Table 3. Percentage of phases composed of $\mathrm{Ti}$ and $\mathrm{O}$ after refinement by Rietveld

\begin{tabular}{ccccc}
\hline & \multicolumn{5}{c}{ Fluency $\left(\mathrm{J} / \mathrm{mm}^{2}\right)$} & $\mathbf{0 . 0 4 8}$ \\
\hline Phases (\%) & $\mathbf{0 . 0 2 3}$ & $\mathbf{0 . 0 3 3}$ & $\mathrm{Am} 2$ & Am4 \\
\hline$\alpha-\mathrm{Ti}$ & $\mathrm{Am} 1$ & $\mathrm{Am2}$ & 15.59 & 19.09 \\
\hline $\mathrm{Ti}_{3} \mathrm{O}$ & 34.39 & 18.35 & 38.36 & 32.26 \\
\hline $\mathrm{Ti}_{6} \mathrm{O}$ & 23.00 & 29.57 & 29.61 & 31.26 \\
\hline $\mathrm{TiO}_{2}$ & 23.84 & 23.19 & 16.44 & 17.39 \\
\hline
\end{tabular}
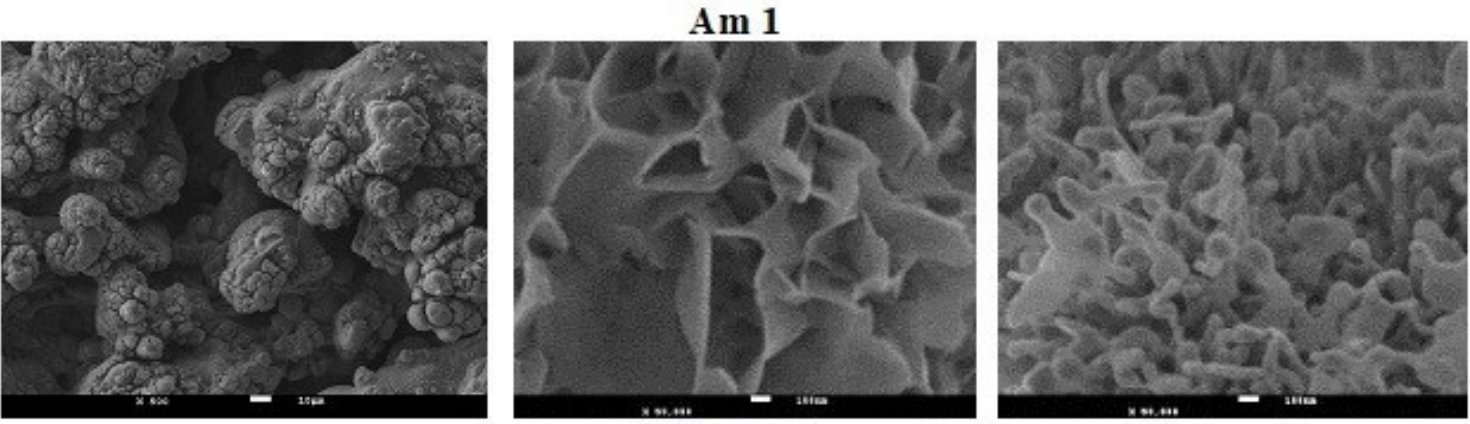

Am 2
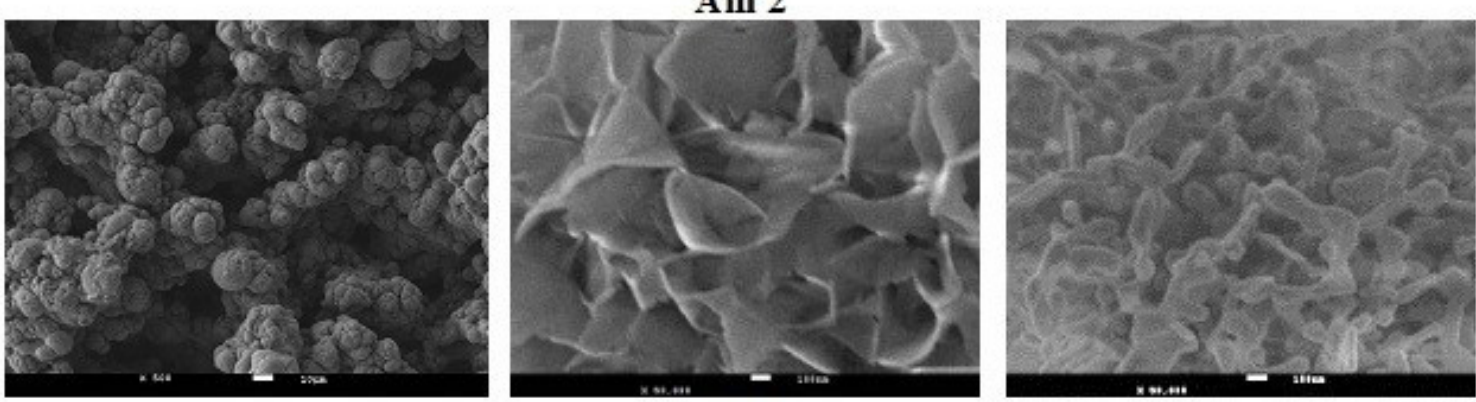

Am 3
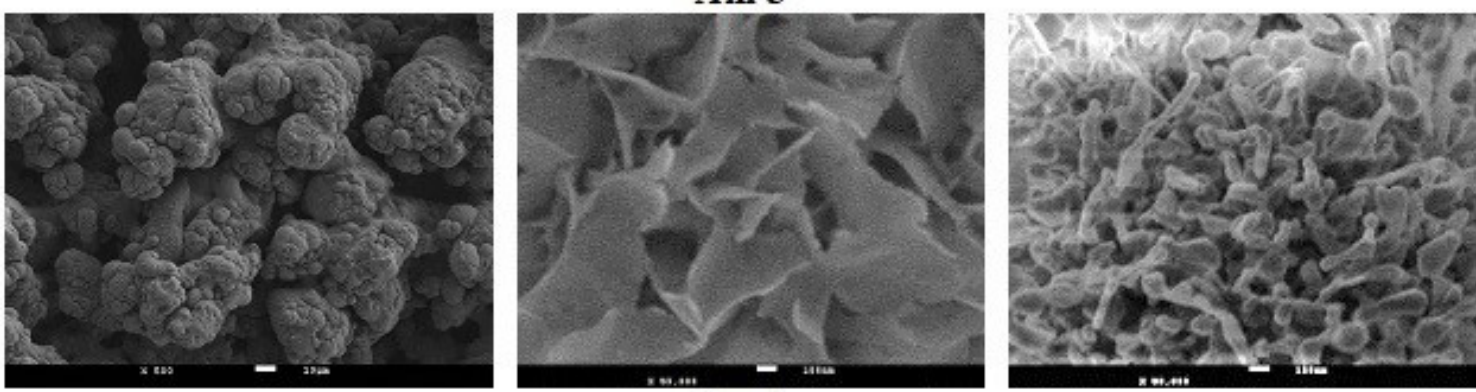

Am 4

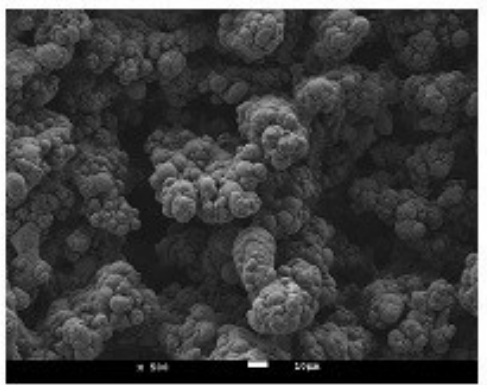

(A)

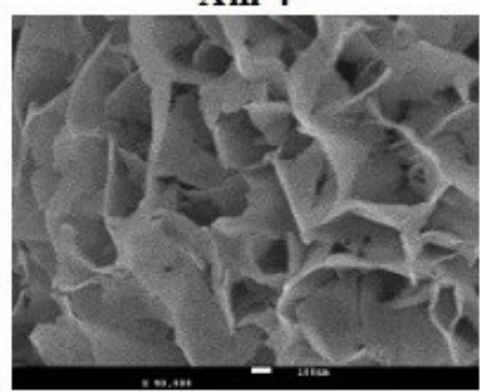

(B)

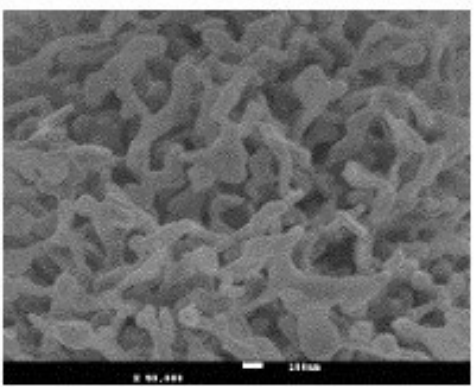

(C)

Figure 1. SEM of the (A) Ti-15Mo alloy submitted to laser beam using different fluences $0.023,0.033,0.040$ and $0.048 \mathrm{~J} / \mathrm{mm}^{2}$ (Samples Am 1, 2, 3 and 4, respectively). 500x; and after coating by immersion in modified SBFMg and heat treatment at (B) $380{ }^{\circ} \mathrm{C}$ and (C) $580{ }^{\circ} \mathrm{C} .50 .000 \mathrm{X}$. 
formation of titanium oxides with different degrees of oxidation by laser ablation. The oxidation mechanism of titanium is complex owing to the high solubility of oxygen in the hexagonal-close-packed (h.c.p.) structure of $\alpha$-titanium. A recent study has shown there are two other potential intersticial site (hexahedral and crowdion) in $\alpha$-Ti where the oxygen can be located ${ }^{32}$. The presence of the $\mathrm{Ti}_{3} \mathrm{O}$ and $\mathrm{Ti}_{6} \mathrm{O}$ substoichiometric phases can be explained by interstitial oxygen diffusion in the Ti lattice ${ }^{33}$.

The X-ray diffraction patterns of the bioceramic coatings, obtained using the SBFMg solution on the surfaces of the samples $\left(1: \mathrm{F}=0.023 \mathrm{~J} / \mathrm{mm}^{2}, 2: 0.033 \mathrm{~J} / \mathrm{mm}^{2}, 3: 0.040 \mathrm{~J} / \mathrm{mm}^{2}\right.$ and $4:$ $0.048 \mathrm{~J} / \mathrm{mm}^{2}$ ), Figure $2 \mathrm{~B}$. All peaks corresponding to the Ti-15Mo alloy (\#: 89-4913) were identified, formation of an ACP 2 phase mixture OCP (\#: 26-1056) and magnesium phosphate (\#: 48-1167) ${ }^{29}$.

The formation of the ACP phase to the HA phase can occur directly from ACP1, whereas its transformation through the formation of intermediates occurs with ACP2 as another intermediate $\mathrm{e}^{2,27,34}$.

The use of the SBFMg solution favors the formation of OCP (octacalcium phosphate) due to the presence of the $\mathrm{Mg}^{2+}$ ion which allowed the crystallization of the ACP 2 and its partial transformation to OCP and the appearance of the magnesium phosphate phase. It was observed the amount of $\mathrm{Mg}^{2+}$ incorporated into calcified tissues associated with the calcium phosphates phase decreases with stronger calcification, leading to changes of the bone matrix that determines the bone fragility ${ }^{13,35}$. Therefore $\mathrm{Mg}^{2+}$ ions were incorporated into calcium phosphate ceramics, it is expected the in vivo process of this synthetic materials is more similar to bone mineral, as compared to $\mathrm{Mg}$ free synthetic materials ${ }^{13,36}$

Figure 2C shows the X-ray diffraction patterns of the bioceramic coatings, obtained using the SBFMg solution on the surfaces of samples 1, 2, 3 and 4. In all samples the peaks corresponding to the Ti-15 Mo (\#: 89-4913), the formation of a mixture of phases tricalcium phosphate $(\beta$-TCP) (\#:70-2065) TCP replaced with magnesium $\mathrm{Ca}_{2,589} \mathrm{Mg}_{0,411}\left(\mathrm{PO}_{4}\right)_{2}$ (\#:87-1582), magnesium phosphate $-\mathrm{Mg}_{3}\left(\mathrm{PO}_{4}\right)_{2}(\#: 48-1167)$ e OCP (\#: 26-1052 $)^{29}$. The formation process of the $\beta$-TCP and $\mathrm{Ca} \mathrm{Mgy}\left(\mathrm{PO}_{4}\right)_{2}$ phases may be related to the decomposition of the non-stoichiometric hydroxyapatite phase, between 600 and $750^{\circ} \mathrm{C}$, reaction below ${ }^{13,27,37,38}$ :

$$
\mathrm{Ca}_{10}\left(\mathrm{PO}_{4}, \mathrm{CO}_{3}\right)_{6}(\mathrm{OH})_{2} \stackrel{2600^{\circ} \mathrm{C}}{\rightarrow} \mathrm{\beta}-\mathrm{Ca}_{3}\left(\mathrm{PO}_{4}\right)_{2}+\mathrm{Ca}_{10}\left(\mathrm{PO}_{4}\right)_{6}(\mathrm{OH})_{2}+\mathrm{CO}_{2} \uparrow
$$

$$
\left(\mathrm{Ca}_{1-x} \mathrm{Mg}_{x}\right)_{9}\left(\mathrm{HPO}_{4}\right)\left(\mathrm{PO}_{4}\right)_{5} \mathrm{OH} \rightarrow 3\left(\mathrm{Ca}_{1-x} \mathrm{Mg}_{x}\right)_{3}\left(\mathrm{PO}_{4}\right)_{2}+\mathrm{H}_{2} \mathrm{O}
$$

$\mathrm{The}_{\mathrm{Mg}}^{2+}$ ion is one of the most abundant trace ions in biological hard tissues. In dental enamel, the concentration is $0.4 \%$, in the $1 \%$ dentin and in the bone $0.5 \%$. The amount of $\mathrm{Mg}^{2+}$ in dental enamel increases from the surface to the enamel / dentin junction area. The properties of calcium phosphates of biological interest can be affected by the presence of $\mathrm{Mg}^{2+}$. This ion has been reported as responsible

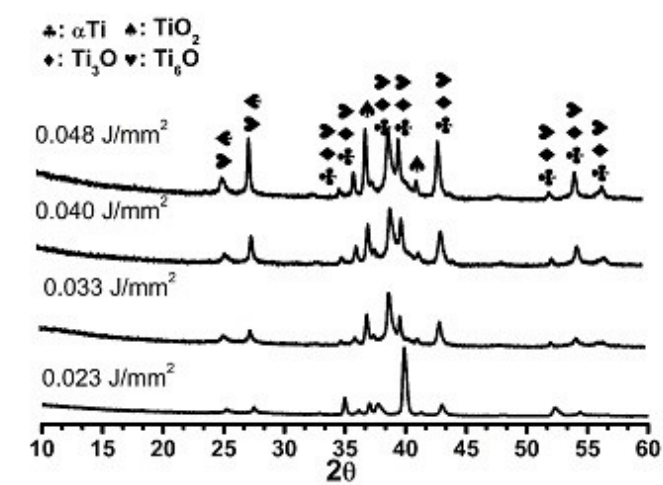

(A)

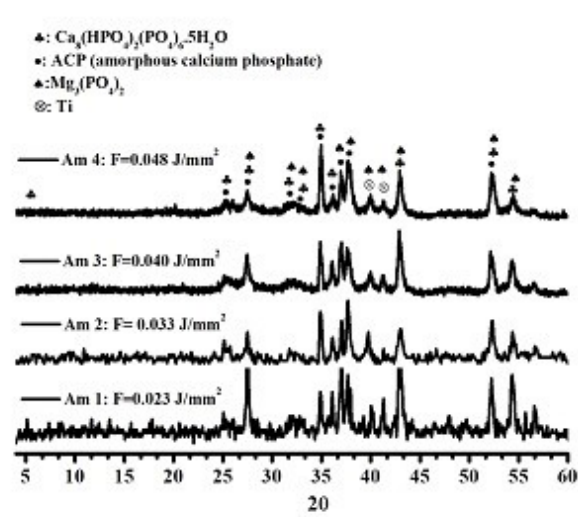

(B)
\&: $\mathrm{Ca}_{3}\left(\mathrm{HPO}_{4}\right)_{2}\left(\mathrm{PO}_{4}\right)_{6} \mathrm{SH}_{2} \mathrm{O}$ ○: Ti

$\because\left(\mathrm{Cr}_{2, s s} \mathrm{Mg}_{2,412}\right)\left(\mathrm{PO}_{4}\right)_{2}$

$\Delta: \mathrm{Mg}_{3}\left(\mathrm{PO}_{4}\right)_{2}$

: $:\left[-\mathrm{Ca}_{3}\left(\mathrm{PO}_{4}\right)_{3}\right.$

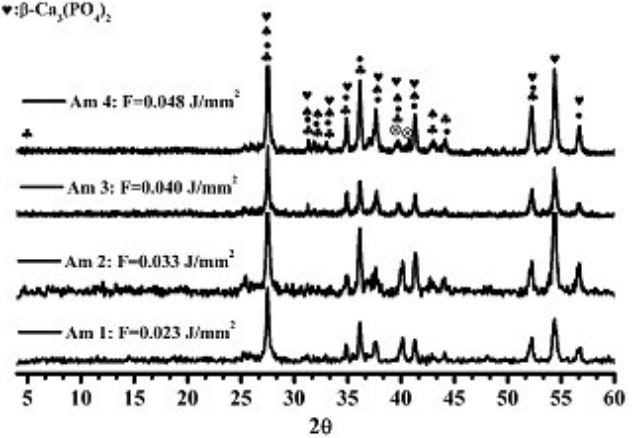

(C)

Figure 2. X-ray diffraction samples $0.023,0.033,0.040$ and $0.048 \mathrm{~J} / \mathrm{mm}^{2}$, before (2A) after calcium phosphate coatings obtained by immersion in SBFMg and heat treated at $380^{\circ} \mathrm{C}(2 \mathrm{~B})$ and $580{ }^{\circ} \mathrm{C}(2 \mathrm{C})$. 


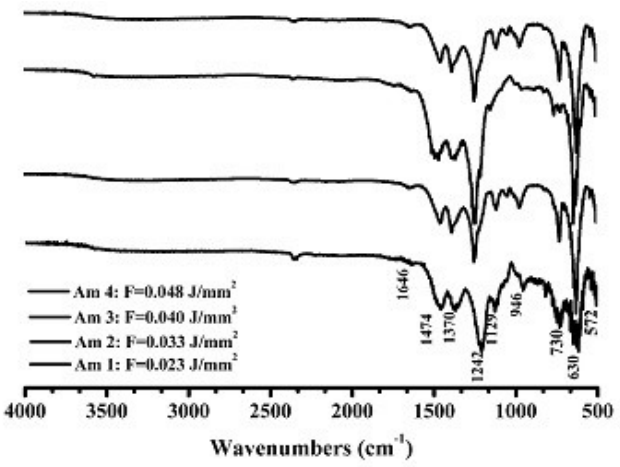

(A)

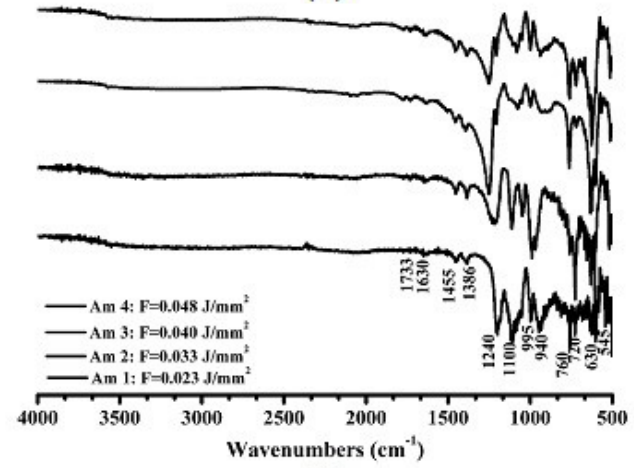

(B)

Figure 3. Absorption spectrum in the medium infrared (FTIR) of the samples (1,2, 3 and 4), after coating of calcium phosphates obtained by immersion in SBFMg and heat treated at (A) $380^{\circ} \mathrm{C}$ and (B) $580^{\circ} \mathrm{C}$.

for the calcium phosphate crystallization disorder, especially $\mathrm{HA}$, when present in the solution in quantities sufficient to compete with $\mathrm{Ca}^{2+}$ ions. Studies have shown that when the $\mathrm{Mg} / \mathrm{Ca}$ molar ratio of the solution is greater than 0.05 , formation of $\mathrm{Mg}^{2+-}$ substituted TCP will occur ${ }^{13,37-39}$.

\subsection{Fourier transform infrared spectroscopy}

The spectra in the middle infrared region of the bioceramic coatings using the SBFMg solution on the surfaces of samples 1, 2, 3 and 4 are shown in Figure $3 \mathrm{~A} 380{ }^{\circ} \mathrm{C}$ and $3 \mathrm{~B} 580{ }^{\circ} \mathrm{C}$.

In the Figure 3B, it can be observed that all the spectra present bands in the regions between $1129-946$ and $730 \mathrm{~cm}^{-1}$ which indicate the asymmetric stretching of the P-O-P bond, and a band in the $1242 \mathrm{~cm}^{-1}$ region relative to the $\mathrm{P}=\mathrm{O}$ stretch $^{40,41}$. For samples (1, 2, 3 and 4), the bands 630 and $572 \mathrm{~cm}^{-1}$ were associated with the stretching of the $\mathrm{OH}$-group, the vibration of the $\mathrm{PO}_{4}{ }^{3-}$ group and the depletion of the $\mathrm{PO}_{4}{ }^{3-}$ group ${ }^{42}$. The band at $1646 \mathrm{~cm}^{-1}$ is due to the incorporation of water molecules. The bands at 1370 and $1474 \mathrm{~cm}^{-1}$ may be associated with the vibration of the $\mathrm{CO}_{3}{ }^{2-}$ group, from the $\mathrm{CO}_{2}$ of the atmosphere during the processes of dissolution, agitation, reaction and calcination, or to the formation of carbonated hydroxyapatite due to the possibility of substitutions occurring of the ions $\mathrm{PO}_{4}^{3-}$ or hydroxyl of the hydroxyapatite by the ion $\mathrm{CO}_{3}^{2-24,27,41,43,44}$.

For the coatings using modified SBFMg at $580^{\circ} \mathrm{C}$ (Figure $3 \mathrm{~B}$ ), all the spectra bands in the regions between 1240-940 and 760-720 $\mathrm{cm}^{-1}$ which indicate the asymmetric stretching of the P-O-P bond, and a band in the $1240 \mathrm{~cm}^{-1}$ region relative to the stretching of $\mathrm{P}=\mathrm{O}^{40,41}$. In all samples $(1,2,3$ and 4$)$ the presence of the 630 and $545 \mathrm{~cm}^{-1}$ regions was observed, which may be associated with the $\mathrm{OH}^{-}$group stretching, the $\mathrm{PO}_{4}^{3-}$ group vibration and the unfolding of the group $\mathrm{PO}_{4}{ }^{3-}$ and refer to the probable formation of the hydroxyapatite phase $\mathrm{e}^{2,42,45}$. Bands in the region of $1733-1630 \mathrm{~cm}^{-1}$ are attributed to the incorporation of water molecules. The bands $1386-1455 \mathrm{~cm}^{-1}$ may be associated with the $\mathrm{CO}_{3}^{2-}$, vibration from the $\mathrm{CO}_{2}$ of the atmosphere during the processes of dissolution, agitation, reaction and calcination ${ }^{24,27,41,43,44}$,

\section{Conclusion}

Bioceramics coatings have been deposited on metal and its alloy surfaces by laser ablation process. Multiphasic calcium phosphates must exhibit a combination of enhanced bioactivity and mechanical stability that is difficult to obtain in single-phase materials. In the present study, it has been also demonstrated the formation of different stoichiometric and non-stoichiometric oxides, such as $\alpha$-Ti, $\mathrm{TiO}_{2}, \mathrm{Ti}_{3} \mathrm{O}, \mathrm{Ti}_{6} \mathrm{O}$, as well as the different oxide percentages depending on the applied fluency. This aspect has provide typical morphologies of the calcium phosphates phases. In this perspective, a multiphase bioceramic coatings on Ti-15Mo surfaces could be obtained depending on the thermal tratment performed to 380 and $580^{\circ} \mathrm{C}$. Therefore, the multiphase bioceramic coatings deposited on Ti-15Mo surfaces can be further improved by providing an biocompatible and long term performance for biomedical applications, including bone regeneration in orthopaedics, oral and maxillofacial surgery.

\section{Acknowledgments}

This work has been supported by CNPq - The Brazilian Council for Research and Scientific Development.

\section{References}

1. Best SM, Porter AE, Thian ES, Huang J. Bioceramics: Past, present and for the future. J Eur Ceram Soc. [serial on the Internet]. 2008 [cited 2019 May 8];28:1319-27. Available from: https://www.sciencedirect.com/science/article/abs/pii/ S0955221907005961

2. Santos ML, Santos Riccardi C, Almeida E Fo, Guastaldi AC. Sol-gel based calcium phosphates coatings deposited on binary Ti-Mo alloys modified by laser beam irradiation for biomaterial/ clinical applications. J Mater Sci Mater Med. [serial on the Internet]. 2018 Jun [cited 2019 Jun 5];29(6):82. Available from: http://www.ncbi.nlm.nih.gov/pubmed/29892909

3. Braga FJC, Marques RFC, Filho EDA, Guastaldi AC. Surface modification of Ti dental implants by Nd:YVO 4 laser irradiation. Appl Surf Sci. [serial on the Internet]. 2007 [cited 2019 Apr 22];253(23):9203-08. Available from: www.elsevier.com/locate/ apsusc

4. Tas AC. The use of physiological solutions or media in calcium phosphate synthesis and processing. Acta Biomater. [serial on the Internet]. 2014 May [cited 2019 May 8];10(5):1771-92. Available from: https://linkinghub.elsevier.com/retrieve/pii/ S1742706113006521

5. Pires LC, Guastaldi FPS, Nogueira AVB, Oliveira NTC, Guastaldi AC, Cirelli JA. Physicochemical, morphological, 
and biological analyses of Ti-15Mo alloy surface modified by laser beam irradiation. Lasers Med. Sci. [serial on the Internet]. 2019 Apr [cited 2020 May 11];34(3):537-46. Available from: http://www.ncbi.nlm.nih.gov/pubmed/30259335

6. Eliaz N, Metoki N. Calcium phosphate bioceramics: A review of their history, structure, properties, coating technologies and biomedical applications. Materials (Basel). 2017;10(4):334.

7. Su Y, Cockerill I, Zheng Y, Tang L, Qin Y-X, Zhu D. Biofunctionalization of metallic implants by calcium phosphate coatings. Bioact. Mater. 2019;4:196-206. https://doi.org/10.1016/j. bioactmat.2019.05.001

8. Aoki H. Science and medical applications of hydroxyapatite [Internet]. Tokyo: JAAS; 1991 [cited 2019 May 8]. Available from: https://www.worldcat.org/title/science-and-medicalapplications-of-hydroxyapatite/oclc/25854150

9. Campbell AA. Bioceramics for implant coatings. Mater. Today [serial on the Internet]. 2003 Nov [cited 2019 May 8];6:26-30. Available from: https://www.sciencedirect.com/science/article/ pii/S1369702103011283

10. Julien M, Khairoun I, LeGeros RZ, Delplace S, Pilet P, Weiss $\mathrm{P}$, et al. Physico-chemical-mechanical and in vitro biological properties of calcium phosphate cements with doped amorphous calcium phosphates. Biomaterials [serial on the Internet]. 2007 Feb [cited 2019 May 8];28:956-65. Available from: http://www. ncbi.nlm.nih.gov/pubmed/17123598

11. Guastaldi AC, Aparecida AH. Fosfatos de cálcio de interesse biológico: importância como biomateriais, propriedades e métodos de obtenção de recobrimentos. Quim. Nova [serial on the Internet]. 2010 [cited 2019 May 8];33(6):1352-58. Available from: http://www.scielo.br/scielo.php?script=sci arttext\&pid=S0100-40422010000600025\&lng=pt\&nrm=iso $\&$ tlng $=\mathrm{pt}$

12. Nabiyouni M, Brückner T, Zhou H, Gbureck U, Bhaduri SB. Magnesium-based bioceramics in orthopedic applications. Acta Biomater. 2018;66:23-43. http://dx.doi.org/10.1016/j. actbio.2017.11.033.

13. Marchi J, Dantas ACS, Greil P, et al. Influence of Mg-substitution on the physicochemical properties of calcium phosphate powders. Materials Research Bulletin. 2006 [cited 2019 May 8];42(2007):1040-50. Available from: www.elsevier.com/locate/ matresbu

14. Bigi A, Cojazzi G, Panzavolta S, Ripamonti A, Roveri N, Romanello M, et al. Chemical and structural characterization of the mineral phase from cortical and trabecular bone. J. Inorg. Biochem. [serial on the Internet]. 1997 Oct [cited 2019 May 8];68:45-51. Available from: http://www.ncbi.nlm.nih.gov/ pubmed/9379180

15. del Valle García A, Hautcoeur D, Leriche A, Cambier F, Baudín C. Microstructural design of ceramics for bone regeneration. $\mathrm{J}$ Eur Ceram Soc. 2020;40:2555-65.

16. Kokubo T, Takadama H. How useful is SBF in predicting in vivo bone bioactivity? Biomaterials [serial on the Internet]. 2006 May [cited 2019 May 8];27:2907-15. Available from: http://www.ncbi.nlm.nih.gov/pubmed/16448693

17. Barrére F, Layrolle P, van Blitterswijk CA, Groot K. Biomimetic calcium phosphate coatings on Ti6AI4V: a crystal growth study of octacalcium phosphate and inhibition by $\mathrm{Mg} 2+$ and HCO3-. Bone Aug [serial on the Internet]. 1999 [cited 2019 May 8];25:107S-111S. Available from: http://www.ncbi.nlm. nih.gov/pubmed/10458288

18. Barrere F, van Blitterswijk CA, de Groot K, Layrolle P. Nucleation of biomimetic CaP coatings on Ti6Al4V from a $\mathrm{SBF} \times 5$ solution: influence of magnesium. Biomaterials [serial on the Internet]. 2002 Aug [cited 2019 May 8];23:2211-20. Available from: https://www.academia.edu/3580502/Nucleation of_biomimetic_Ca_P_coatings_on_Ti6Al4V_from_a_SBF_5 solution_influence_of_magnesium?auto=download.
19. Lin X, de Groot K, Wang D, Hu Q, Wismeijer D, Liu Y. A review paper on biomimetic calcium phosphate coatings. Open Biomed Eng J. 2015;9:56-64.

20. Aparecida AH, Fook MVL, Santos ML, Guastaldi AC. Estudo da influência dos íons $\mathrm{K}+, \mathrm{Mg} 2+$, SO4(2-) e CO3(2-) na cristalização biomimética de fosfato de cálcio amorfo (ACP) e conversão a fosfato octacálcico (OCP). Quim Nova [serial on the Internet]. 2007 Jul-Aug [cited 2019 May 8];30:892-96. Available from: http://www.scielo.br/scielo.php?script=sci_arttext\&pid=S010040422007000400024\&lng=pt\&nrm=iso\&tlng=pt

21. Lavisse L, Grevey D, Langlade C, Vannes B. The early stage of the laser-induced oxidation of titanium substrates. [serial on the Internet]. Appl Surf Sci. 2002 [cited 2019 May 8];186(2002):15055. Available from: https://iutchalon.u-bourgogne.fr/wp-content/ uploads/2013/03/App1SurfSc_186_2002.pdf

22. Dekker RJ, de Bruijn JD, Stigter M, Barrere F, Layrolle P, van Blitterswijk CA. Bone tissue engineering on amorphous carbonated apatite and crystalline octacalcium phosphate-coated titanium discs. Biomaterials [serial on the Internet]. $2005 \mathrm{Sept}$ [cited 2019 May 8];26:5231-39. Available from: http://www. ncbi.nlm.nih.gov/pubmed/15792550

23. Chen S, Guan S, Li W, Wang H, Chen J, Wang Y, et al. In vivo degradation and bone response of a composite coating on $\mathrm{Mg}$ $\mathrm{Zn}-\mathrm{Ca}$ alloy prepared by microarc oxidation and electrochemical deposition. J. Biomed. Mater. Res. - Part B Appl. Biomater. 2012;100 B:533-543.

24. Li K, Wang B, Yan B, Lu W. Microstructure, in vitro corrosion and cytotoxicity of Ca-P coatings on ZK60 magnesium alloy prepared by simple chemical conversion and heat treatment. J. Biomater. Appl. [serial on the Internet]. 2013 Sep [cited 2019 May 8];28:375-84. Available from: http://www.ncbi.nlm.nih. gov/pubmed/22807584

25. Wang H, Guan S, Wang Y, Liu H, Wang H, Wang L et al. In vivo degradation behavior of Ca-deficient hydroxyapatite coated $\mathrm{Mg}-\mathrm{Zn}-\mathrm{Ca}$ alloy for bone implant application. Colloids Surfaces B Biointerfaces [serial on the Internet]. 2011 Nov [cited 2020 May 13];88:254-59. Available from: http:/www.ncbi.nlm.nih. gov/pubmed/21783346

26. Imaizumi H, Sakurai M, Kashimoto O, Kikawa T, Suzuki O. Comparative study on Osteoconductivity by Synthetic Octacalcium phosphate and sintered hydroxyapatite in rabbit bone marrow. Calcif. Tissue Int. [serial on the Internet]. 2006 Jan [cited 2019 May 8];78:45-54. Available from: http://link. springer.com/10.1007/s00223-005-0170-0

27. Kanazawa T. Inorganic phosphate materials. Tokyo: Kodansha; 1989.

28. Vercik LCO, Assis CM, Fook MVL, Santos ML, Guastaldi AC. Recobrimento de apatitas \&quot;in vitro\&quot; sobre titânio: influência do tratamento térmico. Eclética Química [serial on the Internet]. 2003 [cited 2019 May 8];28:25-31. Available from: http://www.scielo.br/scielo.php?script=sci_arttext\&pid=S010046702003000100003\&lng=pt\&tlng $=\mathrm{pt}$

29. Eclet. Quim. [serial on the Internet]. 1986;1(1). [cited 2019 May 8]. Available from: https://www.icdd.com/powder-diffractionjournal-volume-1/

30. Rietveld HM. IUCr. A profile refinement method for nuclear and magnetic structures. J Appl Crystallogr. [serial on the Internet]. 1969 [cited 2019 Apr 22];2:65-71. Available from: http://scripts.iucr.org/cgi-bin/paper?S0021889869006558

31. Santos ML, Santos Riccardi C, Almeida E Fo, Guastaldi AC. Calcium phosphates of biological importance based coatings deposited on Ti-15Mo alloy modified by laser beam irradiation for dental and orthopedic applications. Ceram Int. 2018;44:224328.

32. Baillieux J, Poquillon D, Malard B. Relationship between the volume of the unit cell of hexagonal-close-packed Ti, hardness and oxygen content after $\alpha$-case formation in Ti-6Al-2Sn-4Zr2Mo-0.1Si alloy. J. Appl. Crystallogr. [serial on the Internet]. 
2016 [cited 2019 May 8];49:175-181. Available from: https:// hal.archives-ouvertes.fr/hal-01755484/document

33. Sorensen OT. Nonstoichiometric oxides. New York: Academic Press; 1981.

34. György E, Pérez del Pino A, Serra P, Morenza JL. Chemical composition of dome-shaped structures grown on titanium by multi-pulse Nd:YAG laser irradiation. Appl Surf Sci. [serial on the Internet]. 2004 [cited 2019 Apr 22];222(1-4):415-22. Available from: https://linkinghub.elsevier.com/retrieve/pii/S0169433203011450

35. Raynaud S, Champion E, Bernache-Assollant D, Thomas P. Calcium phosphate apatites with variable $\mathrm{Ca} / \mathrm{P}$ atomic ratio I. Synthesis, characterisation and thermal stability of powders. Biomaterials [serial on the Internet]. 2002 Feb [cited 2019 May 8];23:1065-72. Available from: http://www.ncbi.nlm.nih.gov/ pubmed/11791909

36. Kai KC, Cunha TF, Higa OZ, Marchi J. Avaliação da citotoxicidade de cerâmicas de fosfato tricálcico dopadas com magnésio e zinco In: Congresso Latino Americano de Orgãos Artificiais e Biomateriais [serial on the Internet]; 22-25 de Agosto de 2012; Natal, RN. Proceedings. [cited 2019 May 8]. Available from: https://www.ipen.br/biblioteca/2012/eventos/18989.pdf

37. Correia MB, Júnior JPG, Macedo MCSS, Resende CX, Santos EA. Effect of $\mathrm{Mg} 2+$ on acidic calcium phosphate phases grown by electrodeposition. J Cryst Growth. 2017;475:328-33.

38. Purgstaller B, Konrad F, Dietzel M, Immenhauser A, Mavromatis V. Control of $\mathrm{Mg} 2+/ \mathrm{Ca} 2+$ Activity Ratio on the Formation of Crystalline Carbonate Minerals via an Amorphous Precursor. Cryst Growth Des. 2017;17:1069-78.

39. Mayer I, Schlam R, Featherstone JD. Magnesium-containing carbonate apatites. J Inorg Biochem. [serial on the Internet]. 1997 Apr [cited 2019 May 8];66(1):1-6. Available from: http:// www.ncbi.nlm.nih.gov/pubmed/9076968
40. Sánchez-Salcedo S, Balas F, Izquierdo-Barba I, Vallet-Regí M. In vitro structural changes in porous HA/beta-TCP scaffolds in simulated body fluid. Acta Biomater. [serial on the Internet]. 2009 [cited 2019 May 8];5(7):2738-2751. Available from: http://www.ncbi.nlm.nih.gov/pubmed/19394904

41. Sukjai O, Asanithi P, Limsuwan S, Limsuwan P. Growth of hydroxyapatite on sericin coated and non-sericin coated silk fibers using simulated body fluid. Int J Sci Res Publ. [serial on the Internet]. 2013 [cited 2019 May 8];3(8):1-5. Available from: www.ijsrp.org

42. Chen J, Wang Y, Chen X, Ren L, Lai C, He W, et al. A simple sol-gel technique for synthesis of nanostructured hydroxyapatite, tricalcium phosphate and biphasic powders. Mater Lett. [serial on the Internet]. 2011 [cited 2019 May 8];65(12):1923-26. Available from: https://linkinghub.elsevier.com/retrieve/pii/ S0167577X11003314

43. Gibson IR, Bonfield W. Novel synthesis and characterization of an AB-type carbonate-substituted hydroxyapatite. J Biomed Mater Res. [serial on the Internet]. 2002 Mar [cited 2019 May 8];59(4):697-708. Available from: http://www.ncbi.nlm.nih. gov/pubmed/11774332

44. Breding K, Jimbo R, Hayashi M, Xue Y, Mustafa K, Andersson $\mathrm{M}$. The effect of hydroxyapatite nanocrystals on osseointegration of titanium implants: an in vivo rabbit study. Int J Dent. [serial on the Internet]. 2014 [cited 2019 May 8];2014:1-9. Available from: http://www.hindawi.com/journals/ijd/2014/171305/

45. Gan L, Pilliar R. Calcium phosphate sol-gel-derived thin films on porous-surfaced implants for enhanced osteoconductivity. Part I: Synthesis and characterization. Biomaterials [serial on the Internet]. 2004 [cited 2019 May 8];25:5303-12. Available from: http://www.ncbi.nlm.nih. gov/pubmed/15110481. 